Article

\title{
Sustainable Urbanization on Occupied Land? The Politics of Infrastructure Development and Resettlement in Beira City, Mozambique
}

\author{
Murtah Shannon ${ }^{1, *}$, Kei Otsuki ${ }^{1}$, Annelies Zoomers ${ }^{1}$ and Mayke Kaag ${ }^{2}$ \\ 1 Department of Human Geography and Planning, University of Utrecht, 3584CB Utrecht, The Netherlands; \\ k.otsuki@uu.nl (K.O.); e.b.zoomers@uu.nl (A.Z.) \\ 2 African Studies Centre, 2300RB Leiden, The Netherlands; m.m.a.kaag@asc.leidenuniv.nl \\ * Correspondence: m.l.shannon@uu.nl; Tel.: +31-618088187
}

Received: 30 July 2018; Accepted: 29 August 2018; Published: 1 September 2018

\begin{abstract}
With this article we contribute to debates on urban land governance and sustainable urban development in Africa by providing an empirical analysis of forced displacement and resettlement associated with infrastructure development in Beira city, Mozambique. In recent years Beira has become the recipient of numerous investment flows targeting the built environment by a range of international investors. By analyzing the micropolitical engagements associated with three different infrastructure projects, based on extensive qualitative interviews, observations, and document analysis, we demonstrate how each intervention has been associated with highly informal and divergent processes of forced displacement and resettlement. We argue that these land related impacts have been annexed from debates on sustainable infrastructure development, and that they exhibit some fundamental differences from established resettlement research. We conclude by arguing that forced displacement and resettlement should be understood as a deliberate and systematic feature of urban infrastructure development, through which new social-spatial arrangements are created. This ultimately points to the emergence of a novel mode of fragmented urbanism within the context of urban development in Africa which poses new challenges to urban sustainability.
\end{abstract}

Keywords: infrastructure development; resettlement; African urbanism; sustainable urbanization; urban land governance; forced displacement

\section{Introduction}

The port city of Beira, Mozambique's second largest, has recently become the recipient of hundreds of millions of dollars in investments from various international donors, targeting the expansion of the city's infrastructure. For a city long characterized by unplanned urbanization, dilapidation, and extreme vulnerability to flooding, these new investment flows represent an unprecedented modernization effort under the current municipal government. It is due to their ability to attract high profile infrastructure investments that Beira's leadership has received substantial praise from a range of international donors, branding the municipality as a poster child for effective urban governance in Africa.

Ranging from public green space to economic infrastructure, these investments serve a variety of societal purposes and interests, thus defying sweeping categorizations. Despite their differences however, many investments have shared the common feature of disrupting established land uses, resulting in forced displacement and resettlement. In contrast to the high profile interventions which instigated their creation however, these dynamics have occurred largely outside the public eye, annexed from the city's development narrative. It is here, in the shadows of the primary intervention, that we see investment flows leading to the creation of new urban spaces to house the displaced. 
In recent years infrastructure development has emerged as a priority concern within the context of African urban development, advocated for by leading development institutions and critical scholars alike [1-3]. As a result, historically neglected cities, such as Beira, are now becoming the benefactors of international investment flows targeting the built environment $[4,5]$. As seen in Beira however, urban infrastructure development often comes hand in hand with forced displacement, as infrastructure development is inherently premised on the availability of land, which in the context of African urbanism is always someone's land. So far however, debates on African infrastructure development have not addressed these land-related impacts, focusing instead on the societal value of new infrastructures. It is against this background that a new 'urban land debate' has emerged, with scholars arguing that land governance must be factored into debates on sustainable urban development $[4,5]$.

How forced displacement and resettlement play out in the urban context, and how they relate to issues of urban sustainability, is currently poorly understood however. It is against this background that this article aims to contribute to debates on urban land governance and sustainable urban development in Africa, through empirical and conceptual exploration of forced displacement and resettlement in Beira city. Our objectives here are twofold; (1) to provide an empirical investigation of the displacement and resettlement processes associated with three distinct infrastructure interventions in Beira and (2) to provide conceptual reflections on how these dynamic should be understood within frameworks of sustainable urban development.

We do so by analyzing the displacement 'micropolitics' $[6,7]$ underlying three recent high profile infrastructure interventions in Beira, each associated with a different international financer. With this analysis we reveal that each intervention has been associated with distinct micropolitical constellations, resulting in three highly divergent and informal resettlement processes. We argue that the urban context, as seen in Beira, provides distinct institutional and political challenges not yet observed in established resettlement literature, which has focused predominantly on rural realm interventions. From a conceptual perspective we argue that displacement and resettlement should be understood not just as a destructive process, but as a creative one as well, whereby 'primary' infrastructure investments instigate the creation of 'secondary' resettlement spaces. We argue that this 'creative' process is both a deliberate and systematic feature of urban infrastructure development, and that it should be brought to the foreground in frameworks of sustainable urban development.

We begin our discussion with contemporary debates on African infrastructure development and the urban land question, focusing particularly on the issue of 'Development Induced Displacement' (DID) and resettlement. Following this we provide a discussion of urban development and land governance in Beira. After this we delve in-depth into empirical findings of three recent cases of infrastructure development, encompassing the development of a Special Economic Zone (SEZ), urban river rehabilitation, and storm water drainage, each associated with different donors and resulting in divergent displacement and resettlement dynamics. By distinguishing three consecutive analytical moments of flow mobilization, space clearing, and new urban spaces, we trace the mobilization, negotiation, and congealing of these flows into new urban spaces. We conclude by offering some reflections on the topic of urban sustainability, arguing that DID and resettlement should be at to the forefront of contemporary debates on infrastructure development in Africa.

\section{Urban Development and the Urban Land Question in Africa}

\subsection{The Infrastructural Turn in African Urban Development}

In recent years infrastructure development has emerged as a priority concern within the context of African urban development among international donors and progressive urban scholars alike [1,2]. It is through this infrastructural turn in African urban development debates, that social, economic, and environmental targets are increasingly understood as a function of the 'right' infrastructures. It is against this background that a range of new (international) modalities and institutional arrangements 
are being established with the aim of mobilizing investments into Africa's cities. Although the implications of these new flows have not yet been analyzed in detail, they are expected to drastically change the nature of African cities [4,5].

Whereas there is a notable consensus for the need for greater investments in Africa's urban infrastructure, this is most certainly not the case with regards to the priorities and interests of the infrastructural agenda itself. As illustrated by the flurry of urban visions promising 'entrepreneurial', 'smart', and 'ecological' urban futures (to name a few), what exactly constitutes the 'right' infrastructure has become the topic of considerable contention [3,8-10]. Critical scholars have pointed to the fact that many of these visions essentially constitute variations of the same top-down market-oriented and techno-rationalist logic, which are ill-suited to realizing progressive urban change $[9,11]$. It is against this background that leading African urbanists have sought a closer engagement with the realms of policy and politics, so as to contribute to the formulation of emancipatory urban change [12]. Advocating for such an approach in a recent GIZ report, Pieterse et al. [3] have called for a new agenda of sustainable urbanization, hinged on the notion of sustainable infrastructure which, among other things, 'depends on the activation of citizens and rights' (p. 15).

What appears to be a general trait of these various frameworks of urban (infrastructure) development however is their tendency to presuppose the availability of land upon which new infrastructures are to be developed. As we know however, urban land in Africa is always someone's land. Intervening in the built environment thus logically implies some displacement of existing land claims $[4,5,9]$. While such impacts are perhaps of little concern to overtly speculative and exclusionary urban frameworks [8,9], they go straight to the heart of progressive frameworks [3], as displacement disproportionately impacts the rights of the urban poor. Although proponents of sustainable infrastructure have also argued for the importance of urban land rights, while simultaneously recognizing the inequity of many urban land use systems in Africa, these concerns have yet to be related explicitly to infrastructure development $[2,13]$. Thus, by debating urban infrastructure in terms of its societal function only, as if it already exists, an important component of its societal impact remains largely obscured.

\subsection{Displacement, Resettlement and the Urban Land Question}

It is this earlier moment, where established land claims are displaced by new claims, which has recently sparked the 'urban land debate' $[4,5]$. Taking cues from debates on rural land grabbing and displacement, scholars have argued that a surge in land-based investments will have far reaching implications for established land claims and livelihoods in targeted cities. Currently however, the land related impacts of urban infrastructure development are both poorly understood and therefore highly uncertain. This issue appears to be similarly overlooked in current policy debates on urban land governance, which have revolved around issues of tenure security and regularization [4]. In countries such as Mozambique however, tenure is fundamentally insecure in the face of urban development undertaken in reference to the public interest, as infrastructure often is, irrespective of the tenure regime in question.

The reality of infrastructure development is that it has historically come hand in hand with so-called 'development induced displacement' (DID), for which resettlement has been the common mitigation measure [14]. Both DID and resettlement have long been among the most contentious topics within development debates, as those relinquishing their home and land for 'development' have routinely been left worse off [15-17]. Despite essentially constituting two sides of the same coin, resettlement is often conceived as a separate policy issue, annexing the experiences of affected people from the development narrative legitimizing their resettlement in the first place. So far however, in-depth resettlement research has focused predominantly on large-scale and one-off interventions in the rural realm $[6,7,17-19]$. What DID and resettlement ultimately mean within the context of urban development, and how it relates to issues of urban sustainability, is therefore largely unknown. 
This is not to say that resettlement, or forced displacement more generally, has not appeared in contemporary urban research in Africa, quite the opposite [20-22]. By focusing on issues of urban political-economy and governance, where resettlement and displacement appear as symptoms of the broader urban dynamics under scrutiny, these contributions provide little understanding of the inner 'micropolitics' where DID and resettlement is negotiated and contested [6,7]. Perhaps more importantly, these contributions have focused on instances of neo-liberal urbanization and its many guises, no doubt due to the contested nature of this framework in urban theory. The net result has been that displacement and resettlement have been discussed as functions of exploitative market-based urban development only, where moral outcry is often both justified and uncomplicated. How we are to relate DID and resettlement to urban development which falls outside the rubrics of neoliberal urbanism remains unclear however.

\subsection{A Framework for Urban DID and Resettlement}

Taking the urban land debate as a general orientation we propose a framework of DID and resettlement which take the land and its claimants as the primary unit of analysis in a dispassionate and comparative manner. This implies bringing the actors and negotiations of DID and resettlement to the foreground, in a manner sensitive to temporal and political contingency. In doing so we build on recent work by Milgroom [6] and Otsuki et al. [7] which has elucidated the project micropolitics shaping DID and resettlement processes.

We use three distinct analytical moments to structure the analysis of the cases discussed here. Flow mobilization refers to the incentives and interests driving the 'primary' infrastructure investment. By identifying the specific actors involved we seek to demystify the political components which make up these development 'flows'. Clearing space is the second moment which we use to analyze the political engagements associated with clearing land for development through the resettlement of former land users. Finally we use New spaces as a means to pull infrastructure development and resettlement into a closer conceptual orbit, by discussing both as new spaces created through these investment flows. By doing so we seek to go past a discussion of livelihood impacts alone, by understanding resettlement as a 'creative' process. By discussing the social-spatial characteristics of these new spaces, focusing particularly on the resettlements, we are then able to debate how these spaces relate to issues of urban sustainability.

\section{Research Context}

\subsection{Contemporary Urban Development in Beira}

Beira city is located in the central Sofala province, it a strategically important port city and Mozambique' second largest with around 500,000 residents. Due to coastal erosion and an extreme vulnerability to urban flooding, it is often described as one of Africa's most climate vulnerable cities. Perhaps most importantly, Beira is historically an opposition stronghold. Long considered a bastion of the RENAMO party - the leading rival of the FRELIMO party which has won all consecutive national elections-Beira's municipality is now ruled by a relatively new opposition party called MDM [23]. Beira's opposition status is widely considered to have resulted in the city's (strategic) neglect at the hands of the central FRELIMO government. The historically contentious relationship between the municipality and central state is broadly recognized as a pervasive feature of Beira's urban governance and civic identity $[24,25]$

In recent years Beira has become the subject of growing interests from international donors however. For, it has emerged as a vital logistical node in Mozambique's coal boom and the Beira Agricultural Growth Corridor (BAGC), a large-scale agricultural modernization initiative [26,27]. Moreover, due to its problematic relationship with the central state, MDM has become particularly adept at minimizing its dependence on the central government by attracting resources from abroad. 
As a result, the city has recently become the recipient of a disproportionate amount of donor investments in the realm of infrastructure, and more generally, the built environment.

These recent and ongoing commitments to Beira city include various water, drainage, and sanitation infrastructure projects by the Arab Bank for Economic Development in Africa (BADEA), the World Bank, the European Union, and Netherlands. River rehabilitation and green space development has been undertaken by the KFW development bank and the World Bank. Several urban planning initiatives have been undertaken with the support of GIZ, the Netherlands, and the World Bank. Coastal protection has occurred with funding from Switzerland. Transport infrastructure has been conducted by China and the Netherlands. Real estate development has been conducted by the Netherlands. Special Economic Zone development has been completed by China. Port dredging has occurred with funding from the Netherlands and port master planning funded by DFID. Taken together these investments represent an unprecedented modernization effort in Beira city. As demonstrated by Shankland \& Cambote however, these investments inevitably flow through the central state, and are therefore often associated with contentious negotiations and political fractionism [25].

\subsection{Urban Land Governance in Beira}

Such a range of interventions in the built environment will inevitably have far reaching implications for established land claims; therefore it is worth briefly discussing the institutional arrangements underlying current land claims in Beira. Urban land governance in Mozambique has historically evolved amidst the contradictions and gaps of successive state regimes [28-31]. This has given rise to a set of institutional practices which bear little relationship to formal bureaucratic laws and regulations [32-34]. This is not a simple story of formality vs. informality however, as these practices are underpinned and regulated by lower levels of the formal municipality bureaucracy. In addition to constituting a relatively stable set of institutional practices, this mode of urban land governance enjoys considerable social legitimacy, arguably more so than 'formal' urban land governance arrangements which often exist only on paper. As a result scholars have described urban land governance in Mozambique as being structured by 'alternative formality' and 'twilight' institutions [32] (p. 424) [33], as they fall outside the (normative) categorizations of formality and informality.

From the perspective of formal land governance, Mozambique is often celebrated for having a progressive land rights framework. The Mozambican land law provides legal recognition of customary and usufruct land tenure, the former being based on 10 years uncontested occupancy, on equal legal footing to land titles allocated by the state. These titles, known as DUATs, are based on a long term use right, as the ownership of land and thus its sale is prohibited by the Mozambican constitution. In the urban context however, considerable ambiguity exists in relation to the land law, as urban land regulations have left out and watered down some of these progressive measures applicable to the 'rural' context only [30,31]. For one, no mention is made of customary land rights in urban regulations. Secondly, usufruct land rights in the urban context can only be formalized in areas where urban planning has been undertaken. A lack of bureaucratic capacity and political will to implement these regulations has meant that urban residents are often not eligible for the formalization of their usufruct rights.

Whereas the sale of land is prohibited according to the logic of formal land governance, it is a central feature of 'alternative formality' where the land market constitutes the primary means of access to land alongside inherence [32]. The logic of 'alternative formality' is premised on the sale of land, often agricultural land or a portion of an existing plot, between a willing buyer and a willing seller, upon which a new a house is then built. These transactions are overseen by local chiefs and the neighborhood secretary, known as the chefe de Bairro, which constitutes the lowest level of the formal municipality administration [33]. Once the new land owner takes up residence they can file for a declaration of occupancy or declaração, which is an affidavit provided by the neighborhood secretary which is required to open bank accounts and engage in formal employment (among other things). The process of overseeing land transactions and providing such affidavits is regularly associated with 
the payment fees to local leaders and the neighborhood secretary, which creates a financial incentive among benefactors for continued (illegal) land transactions. It is nonetheless a system which has been credited with providing a high degree of tenure security $[31,33,34]$

From the perspective of 'formality' the land claims established through 'alternative formality' are based on illegal transactions which are, at best, eligible for usufruct rights after 10 years if in compliance with urban plans developed by the municipality. In the face of urban 'development' however, all tenure is fundamentally insecure as the state is vested with the ability to expropriate land if deemed to be in the public interest. In such instances a broader framework of environmental planning and resettlement/expropriation laws apply, with the latter laws requiring either material resettlements or financial compensation based on the type of intervention. This requires, among other things, involvement of provincial (central) government departments in DID inducing interventions. How these provisions relate the claims of 'alternative formality' are entirely unclear however.

\section{Materials and Methods}

The research findings were collected within the context of an ongoing PhD research on international development cooperation, urban development, and land governance in Beira, for which data collection was undertaken in Mozambique (Maputo and Beira) and the Netherlands between May 2015 and May 2018. Research in Mozambique was undertaken with support of Centro Terra Viva, a Maputo based land rights organization, and the Catholic University of Mozambique in Beira. The findings discussed in this article were based predominantly on data collection undertaken during three separate periods in Beira, consisting of three months between September and November 2015, a similar period in 2016, and one month in between May and June in 2017.

Qualitative interviews constituted the primary date collection method. Eighty in-depth semi-structured interviews were undertaken with representatives of resettled households, including local leaders, who were recruited through door-to-door visits in resettlement locations. Twenty-eight in-depth interviews were undertaken with representatives of key institutional counterparts associated with the resettlements. With regards to the agricultural displacement associated with the drainage rehabilitation project, 22 concise semi-structured interviews were undertaken with household members and local leaders recruited through snowballing in the neighborhoods surrounding the intervention site. As interviews with household respondents of the drainage rehabilitation case were undertaken within two months of the resettlement, an additional 13 concise semi-structured interviews were undertaken six months later to follow-up on their resettlement experience.

In-depth semi-structured interviews with household respondents and institutional counterparts generally took 30-75 min and were organized around predetermined topics. The interviews were undertaken in Portuguese, English, and on occasion, in the local dialects Sena and Ndau. The majority of interviews were undertaken in the accompaniment of one or two local research assistants who provided support with translation (where necessary) and knowledge of community customs and institutions. In accordance with local practice, formal permission was granted by the municipality in written form for undertaking the research in the resettlement communities. Due to sensitivity of the subject matter it was decided against recording interviews in favor of extensive note-taking during interviews which were transcribed electronically later on the same day.

Data collection and analysis was broadly based on grounded approach, whereby the preliminary analysis of data served to further refine the selection of respondents and interview topics in an iterative manner. The final analysis of the transcripts was undertaken using deductive and inductive coding consisting of categories relating to the resettlement process, power relations, institutional legitimacy, and social-spatial outcomes. This data was complemented by extensive field notes, observation, and (project) document and policy analysis. 


\section{Results}

The three interventions discussed in the following section are depicted in Figure 1, showing the respective intervention sites, displacement trajectories and resettlement locations.

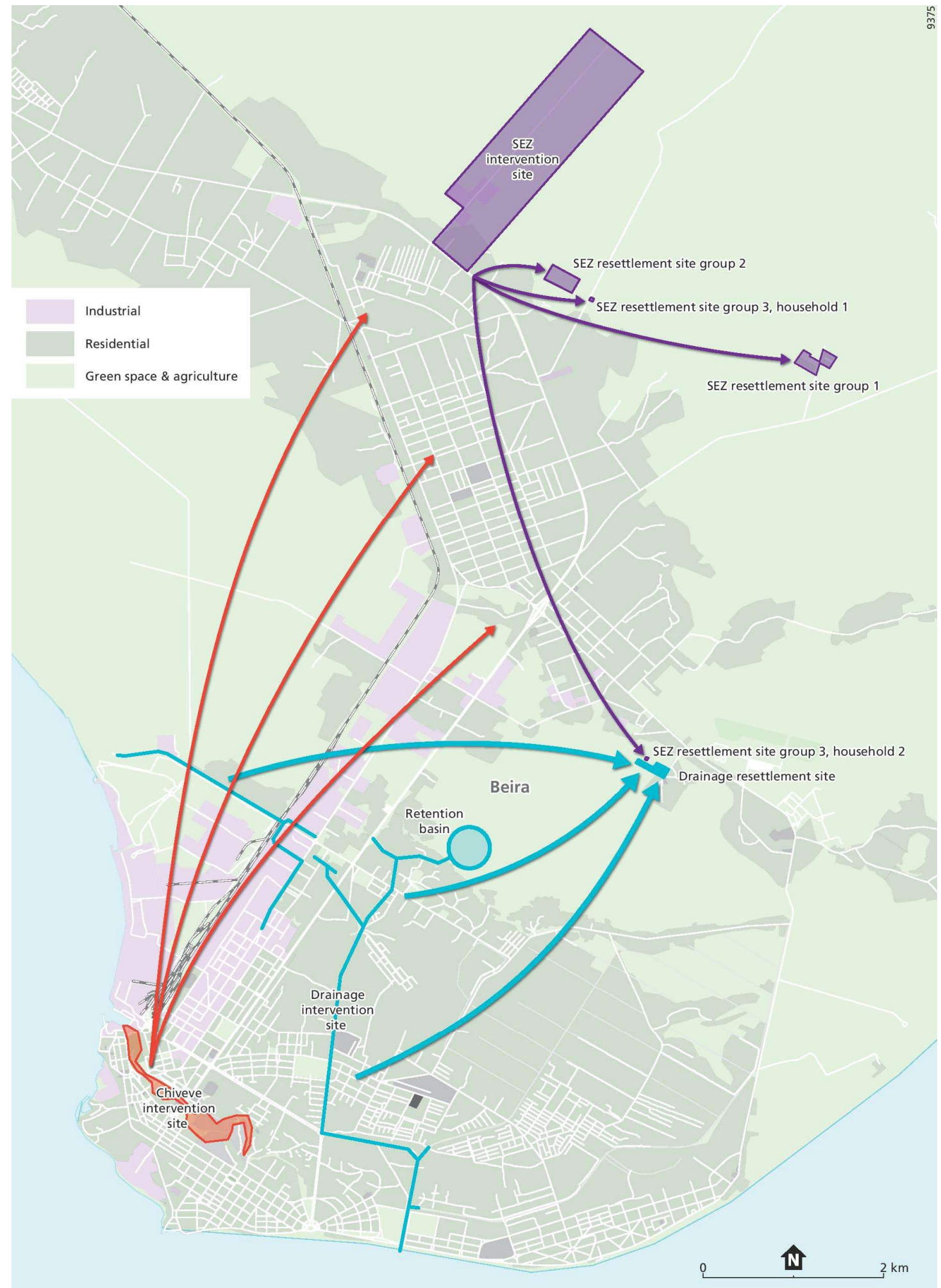

Figure 1. The three intervention sites and their respective resettlement locations. Arrows of the Chiveve resettlement denote the general direction of the 34 households spread out through the city. 


\subsection{The Manga Mungassa Special Economic Zone (SEZ)}

\subsubsection{Mobilizing Investments for the SEZ}

In 2009 the Mozambican government established GAZEDA, a governmental body tasked with the development of Special Economic Zones (SEZ). The SEZ concept is modeled on the Chinese export zones and was adopted through close Sino-Mozambican ties. Beira was identified as the second location for an SEZ which was approved by GAZEDA in 2012. Known as the Manga-Mungassa Special Economic Zone, Beira's SEZ was aimed at becoming a logistics and manufacturing hub within the broader Beira corridor. The SEZ was allocated an area of 217 hectares, with a total of 1000 hectares being earmarked for future expansion. Development and management of the SEZ was awarded to the Chinese SOGECOA company, a subsidiary of the Anhui Foreign Economic Construction Group (AFECC), with total commitments reportedly totaling 500 million US dollars. After its initial designation by GAZEDA, the development of the SEZ was handled primarily by SOGECOA in cooperation with the municipality of Beira.

\subsubsection{Clearing Space for the SEZ}

The Manga-Mungassa SEZ was allocated land in the neighborhood of Mungassa, an area which has been earmarked for commercial expansion by the municipality. Due to its locations along the N6 national highway, Mungassa is well located for logistical enterprises in particular. Currently however, Mungassa is a residential neighborhood set in lush greenery comprising mixed residential and agricultural land use. For residents of Mungassa the N6 plays a crucial role in urban mobility as it constitutes a main artery of Beira's bustling chapa minibus system.

The households living within the allocated area varied in terms of household income, housing conditions, and livelihoods, a demographic diversity not uncommon to Beira's neighborhoods. The SEZ development would ultimately lead to the forced displacement and/or resettlements of circa 110 households and an undetermined amount of small-scale farmers. The households comprised long- and short-term residents, ranging from those which had lived in the area for generations to households which had moved there shortly before the SEZ project became known. The vast majority had bought land in the neighborhood and had constructed their properties incrementally with hired labor. Only two of the households had formal property titles, which they had acquired through the (former) nationalized housing scheme dating from Mozambique's socialist era [29]. The majority had declarations of occupancy from the neighborhood secretary in accordance with established urban governance practices in Mozambique [32-34].

The SEZ constituted the first large-scale resettlement undertaken by the municipality and was associated with widespread conflict between the community and municipality. According to key respondents no formal impact assessments or resettlement planning was undertaken prior to the resettlement as required by Mozambican law. Due to the varied means and response within the community three distinct resettlement groups would ultimately emerge from the resettlement process.

According to the household respondents, SOGECOA had already set up camp behind the Mungassa neighborhood before they were visited by representatives of SOGECOA and the municipality, including the Mayor. During these first engagements a census was made of the households deemed eligible for resettlement. The criteria for eligibility was the subject of considerable contention and based on the permanence of dwellings in Mungassa, based largely on the discretion of the neighborhood secretary. In this initial phase only around 50 households were identified as eligible for resettlement who would come to form the first resettlement group.

During negotiations these households were told that they would receive new houses in close vicinity to their current location. As access to transport and social infrastructure had been their main concern, many respondents agreed to the terms offered, although they admitted to 'not having any choice'. However, a week before their resettlement in 2013 it became apparent that the location had been changed to the peripheral neighborhood of Ndunda, some $3.5 \mathrm{~km}$ from the N6 highway in 
a remote and undeveloped urban expansion area without social infrastructure of public transport. According to respondents of the municipality and SOGECOA, they had not been able to negotiate the necessary land titles to the location initially agreed upon with the community.

Faced with substantial protests due to the new location, the municipality sought to appease various influential households and local leaders by providing them with multiple houses, additional cash compensation, and motorbikes, leading to widespread suspicion of collusion and unfair treatment among the resettled population.

The second resettlement group was formed by households which had been left out of the initial census, on the basis of not owning fully constructed houses in Mungassa at the time. According to the municipality this group consisted of 'opportunists' who sought to illegitimately claim compensation. According to various respondents from the second group however, they had acquired the land in Mungassa without knowing of the pending resettlement, often receiving declarations of occupancy from the neighborhood secretary who had not notified them of the nearing project. With the prospect of losing their investments without compensation, the group formed a committee with appointed representatives, lobbying the municipality and engaging in protests. The group soon expanded to include members from the first group who had refused to relocate to the peripheral area of Ndunda, totaling around 60 households. After such protests were televised on a national news network, the municipality eventually agreed to provide the group with building materials and titled plots in the urban expansion area Mangalene; which is in closer vicinity to social infrastructure then Ndunda but without water or electricity infrastructure.

The third group consisted of the two households which had owned properties with formal titles through the national housing scheme. Both owners had rejected the resettlement terms offered by the project representatives and had taken their complaints to the provincial government, which according to the Mozambican law is required to oversee all resettlements. In doing so, these households displaced significantly more institutional awareness and access than the other community members. As a result, both households were eventually allocated new residential properties in two different locations of considerably higher quality than those of the other two groups. One house was located adjacent to the resettlement location of group two, while the other was located next to the resettlement location of the urban drainage rehabilitation project discussed later.

\subsubsection{The New Urban Spaces of the SEZ Investment}

During the final field visits in 2017 the Manga Mungassa SEZ had begun to rise on the cleared land of the resettled households. Billboards depicting artificial lakes, yacht clubs, and waterfront villas served to inform inquisitive passerby of the constructions underway and that that this was no ordinary manufacturing zone, but a space of worldly luxury far removed from the urban reality of Beira city. For those inquisitive outsiders not content with billboards alone however, towering walls around the SEZ assured that the development inside would remain a mystery to them. Therefore, for the uninitiated majority, the SEZ project constituted something of an urban 'black box'.

Aside from the SEZ we that the intervention lead to the creation of additional urban spaces to house the three resettlement groups which were forged out of the SEZ's micropolitics. For the members of group one, their new space constituted several rows of poorly constructed concrete houses in a peripheral region, some $3.5 \mathrm{~km}$ by foot from public transport in an area of seasonal inundation. Without any social infrastructure in the area families soon found themselves severely restricted in household mobility, with widespread vulnerability and a reduction in overall wellbeing as a consequence. Although the houses had water and electricity connections, many had since been cut of as a result of towering bills. The new neighborhood was also surrounded by a poorly planned drainage network which contained dormant water for large parts of the year, leading to high incidences of waterborne diseases in the community. Some three years after the resettlement, the households had still not received land titles, an issue which many appeared profoundly aware of through the experience of resettlement, further perpetuating a sense of insecurity. 
The families of the second resettlement group found themselves in the new urban space of Mangalene, which was substantially closer to the public transport access of the N6 then Ndunda but without water and electricity infrastructure. As the building materials provided by the municipality were only to construct single bedroom homes, they were required to invest substantial financial resources into additional material and hired labor. This investment threshold meant that many of the plots had not been developed some two years after the resettlement. In contrast to the members of group one in Ndunda however, the residents of group two had in fact received land titles, likely due to the sustained lobbying of the neighborhood commission representing them. As titled land is in high demand among more affluent residents in Beira, the asset value of these households was considerable higher than that of group one, as titled land can easily fetch 10 times that of untitled land. Consequentially, many plots had been sold off allowing families to relocate elsewhere with the earnings of their titled land.

For the vast majority of respondents, the resettlement experience had left traces of deep resentment and distrust towards the municipality, who was clearly distinguished from SOGECOA as being the responsible party. One respondent argued that the intervention would serve as an example for future resettlement stating "future resettlements will be very difficult because people will have learned from the experience in Mungassa". Various respondents of group one and two had also heard of other resettlements, such as the World Bank drainage project (discussed later), which they saw as successful resettlements. The minimal or absent role of the municipality in these other resettlements was seen as evidence that it should be left out of future resettlements. The awareness among these respondents of inconsistent resettlement standards being adopted between various projects served to strengthen the sense of arbitrariness and injustice which they experienced. Although they had eventually received considerably better resettlement terms, the two households of group three were similarly resentful towards the municipality. As a whole, the resettlement had clearly served to diminish any social legitimacy which the municipality had enjoyed among the resettled households of Mungassa.

\subsection{The Chiveve River Rehabilitation Project}

\subsubsection{Mobilizing Investments for the Chiveve River Rehabilitation}

The Chiveve is a small tidal river of $3.5 \mathrm{~km}$ running through downtown Beira that had been closed off in the 1980s. Due to its closure, and years of degradation, the river had become a source of flooding and pollution. As a result, Beira's leadership had been actively seeking donor finance to rehabilitate the river, eventually finding a willing party in the German development bank KFW and the World Bank. Project planning published in 2013 revealed that the Chiveve intervention would consist of two phases constituting distinct projects. The first encompassed the rehabilitation and expansion of the rivers drainage capacity together with the construction of a tidal inlet funded by KFW, while the second encompassed the development of a 20 hectare urban green space with commercial and recreational facilities along the banks of the river. The first phase was financed by the KFW while the second was funded by the KFW and World Bank, both phases totaling circa 31 million USD. As the second phase was not yet underway at the time of the research, we restrict our discussion to the first phase

The rehabilitation phase was associated with several institutional actors during the planning and implementation of the Chiveve project, in addition the KFW and World Bank. AIAS, Mozambique's national sanitation asset holding company, constituted the project owner and formal recipient of project funding. The project design and management was contracted to the German engineering firms CES and Inros Lackner, while construction contracts were awarded to the China Henan International Cooperation Group (CHICO). As the project also required the eviction of households living in the project site, it was agreed between AIAS and the municipality that the latter would take responsibility for resettling the families in question. This constituted an 'informal' agreement as Mozambican law stipulates that resettlements must be coordinated by provincial (central) government departments. 
During the project implementation an additional resettlement consultant was commissioned to oversee the resettlement on behalf of the municipality.

\subsubsection{Clearing Space for the Chiveve River Rehabilitation}

The Chiveve rehabilitation required the resettlement of 34 households and an informal market in late 2011 (although the latter component fell outside the scope of this research). Known as the community of Mangal, the household were characterized by extreme poverty and precarity, residing near the (former) mouth of the Chiveve river. The majority of the respondents stated living there for less than ten years, with some having bought the land and others having simply cleared mangroves on land without pre-existing 'informal' claims. Respondents stated that Mangal was among the only locations accessible to them due to land prices in Beira. None of the respondents had formal titles to their properties. Despite being a hazardous area, the downtown location of Mangal was of crucial importance to the families living there, as many could access social infrastructure and income-generating activities without having to pay for public transport.

Both the KFW and World Bank have formally adopted the World Bank social safeguards in relation to project finance to government recipients. Despite this however, the resettlement was neither reflective of these standards nor of the Mozambican resettlement law, as considerable ambiguity had been cast around the accountability and 'ownership' of the resettlement. This was due to the fact that the municipality had allegedly planned to resettle the Mangal community prior to the involvement of the KFW and World Bank. In project documents of both banks, conflicting accounts were given of the relationship between the rehabilitation project and the resettlement. While a KFW impact assessment spoke of having 'integrated' the resettlement into the project due to a 'certain link with the project implementation', World Bank documentation stated that the rehabilitation project had not required resettlement at all, suggesting it was a parallel yet unrelated initiative undertaken by the municipality. No project funding was provided for the resettlement by the donors, meaning that the available resources were extremely limited.

The ambiguity cast in formal documentation as to the relationship between the resettlement and the river rehabilitation project was strongly contrasted by the reality on the ground. Far from having a 'certain link', or being entirely separate altogether, the resettlement was in fact implemented as a precondition for the completion of the river rehabilitation works. Moreover, the various project stakeholders of the rehabilitation project had been heavily involved in negotiating the resettlement strategy, which led to multiple revisions of the resettlement plan. Due to the fact that each of these plans were successively communicated to the communities and then withdrawn, the process was associated with a great deal of confusion and insecurity among the households as to their fate.

The first strategy, which was briefly detailed in KFW's impact assessment, encompassed the provision of titles plots and building materials in Ndunda (the location of the first SEZ resettlement group); a strategy which is not in accordance with the national resettlement framework which requires the provision of prebuilt houses. This plan was eventually rejected by the KFW and other project stakeholders on the grounds of not meeting social standards, leading to the formulation of a revised strategy encompassing the provision of prebuilt houses. This option was greatly preferred by the Mangal community. However, it soon became apparent that the municipality did not have the necessary resources for the timely provision of such housing. Faced with mounting complications and the prospect of delayed rehabilitation works, an independent resettlement consultant was hired by the municipality and a third and final strategy was developed

The final strategy entailed that the municipality would acquire houses from Beira's housing market, while temporarily relocating the households to rental accommodations throughout the city while the permanent houses were being acquired. The families were informed of this new plan circa ten days before their eviction, along with the demand that they find the rental accommodations themselves with a budget provided by the municipality. The community was eventually evicted at the end of 2014, with the majority of families going on to reside in their rental accommodations for 
six to twelve months before being relocated to their permanent houses acquired by the municipality. These properties consisted of houses in unplanned 'informal' neighborhoods located throughout the city, several kilometers (at least) form the Mangal area. All in all the resettlement was estimated to have cost 10,000 US dollars per household at the time.

As a whole, the resettlement process was unregulated, tellingly referred to by a key respondent as an 'informal resettlement'. For instance monitoring and coordination were undertaken by the municipality independently of the provincial (thus central) government departments legally mandated to so. Political factionism between the central and municipal governments surfaced as a major reason for the municipality to the provincial government and thus the national resettlement law. Similarly, no formal resettlement planning or systematic livelihood rehabilitation was undertaken, as required by both Mozambican law and World Bank standards.

\subsubsection{The New Urban Spaces of the Chiveve River Rehabilitation}

The first phase of the Chiveve intervention was completed in the beginning of 2017 with the public inauguration of the rehabilitated Chiveve river. During the televised inauguration representatives of the central government and municipality became embroiled in a conflict as each sought to take credit for the project, displaying the political significance and underlying factionism of this high profile project. The event revealed a river whose retention capacity had been massively increased ending in a newly constructed 'lagoon' connected to the sea through a tidal gate allowing for controlled water levels. As argued by a key respondent, the Chiveve project was therefore more a feat of heavy engineering than one of 'rehabilitation'. Nonetheless, the city's flood resilience had been greatly increased, soon to be followed up by the development of a 20 hectare city park in the second phase of the Chiveve intervention.

For the former households of Mangal community however, whose homes had made way for the Chiveve lagoon, the Chiveve project had substantially exacerbated their initial poverty and vulnerability. As the project had not been associated with any structured livelihood rehabilitation, aside from incidental temporary work on the Chiveve site, the families found themselves having to adapt twice to the new surroundings of their successive rental and permanent accommodation, several kilometers from Mangal. Although many considered their new houses to be an improvement in terms of housing conditions, various houses suffered from leaking rooves and/or lacked improved sanitation.

Although these houses did not constitute new urban spaces in a physical sense, as they had existed prior to the Chiveve intervention, they were subjected to a set of novel institutional arrangements which suggested that new spaces of governance had been created. During the resettlement negotiations it had been decided that the households were to receive formal land titles to their properties. What is novel in this regard is the fact that urban land titles can only be provided in planned areas according to Mozambican law. As the resettlement houses were located in unplanned 'informal' areas, the land titles provided were therefore of questionable legal standing, essentially constituting a form of 'informal' titling. This suggests that the resettlement process had served to restructure citizen-municipality relations in a manner neither reflective of established land governance practices nor of formal land governance as it is defined in laws and regulations.

\subsection{The Urban Drainage Rehabilitation Project}

\subsubsection{Mobilizing Investments for the Urban Drainage Rehabilitation}

As one Africa's most climate vulnerable countries, Mozambique was identified as a target country of the Pilot Program for Climate Resilience (PPCR), a program financed by the Climate Investment Fund's (CIF) under management of the World Bank. In 2010, during negotiations between the World Bank and Mozambican government over PPCR investment locations, it became apparent that the World Bank and other bilateral donors saw Beira city as an ideal candidate. However, as observed by Shankland \& Cambote [25], factionist interests led the central government to initially resist 
Beira's candidacy. After vigorous lobbying by donors however, Beira was chosen as an investment PPCR location.

It was determined that the finance would go towards the rehabilitation and expansion of Beira's storm water drainage system which dated form the colonial era. The project encompassed the widening and rehabilitation of $9.3 \mathrm{~km}$ of urban drainage infrastructure dating from the colonial era, as well as the construction of a retention basin. The project, estimated at around 45 million USD, constituted the first of a three phase overhaul of the city's drainage infrastructure outlined in a drainage master plan which was developed by the Portuguese engineering firm TPF Planege as part of the PPCR initiative. As with the Chiveve case, AIAS constituted the formal recipient of the funds, with construction contracts being similarly awarded to the China Henan International Cooperation Group (CHICO). As the project also entailed resettlement, the same resettlement consultant of the Chiveve case was contracted to oversee the community engagement.

\subsubsection{Clearing Space for the Urban Drainage Rehabilitation}

For 21 households living along Beira's drainage channels, the urban drainage rehabilitation project implied the destruction of their homes and resettlement to a new area. The construction of a retention basin in the in the central floodplain of Maraza, an area historically used for rice cultivation [28], implied in turn the eviction of 490 small-scale farmers. In contrast to the SEZ and Chiveve case, the resettlement was coordinated by the necessary provincial government departments and subjected to formal resettlement planning, as stipulated by Mozambican law. Similarly, in contrast to these previous cases, was the fact that the project finance included funds earmarked specifically for the resettlement, amounting to circa 60,000 US dollars per house.

The 21 households lived scattered along the drainage channels throughout several neighborhoods. The majority of the families were long term occupants for several decades, some of which stated having acquired property titled through the (former) nationalized housing scheme. Formal notice of the pending resettlement was given in 2014 by the neighborhood secretary and resettlement consultant. The vast majority of the respondents reported that the communication of the resettlement had been well structured and coordinated, encompassing several meetings, in stark contrast to the previous cases. Respondents stated that the neighborhood of Ndunda (location of first group of the SEZ resettlement) had initially been identified, but that it was eventually decided against due to the peripheral location and insufficient social infrastructure. The tranquil area of Mutondo, located next to the floodplain where the retention basin was to be established, was eventually identified as a suitable location. The households were eventually relocated to a purpose built residential area in the second half of 2016.

With regards to the 490 farmers, which occupied a total of circa 610 plots, the project plans stated that they were to receive replacement agricultural land in the neighborhoods of Mungassa and Inhamizua. It was stated explicitly that World Bank regulations prohibited the provision of cash compensation alone. Despite this however, cash compensation was in fact what the vast majority received instead of replacement land, at 5000 meticals per household (65 USD at the time). Two different accounts emerged as to why the resettlement plans were eventually deviated from-in direct contradiction of World Bank standards. According to project staff, the affected farmers had voiced their favor of cash compensation instead of replacement land. According to local leaders however, the farmers had initially been offered money only, not land. According to the latter account land had only been provided to several farmers which had asked for it on their own initiative. Due to these different narratives it was not possible to ascertain the reason why the resettlement plan was deviated from, in apparent contradiction to World Bank standards.

What was clear however, was the fact that the provision of replacement agricultural land was in contradiction to the municipality's own urban development vision, which is premised on the systematic displacement of agricultural land use from the city. In fact both Mungassa and Inhamizua constitute areas which have been earmarked for future urban expansion. The provision of replacement land in these areas would therefore not have constituted a long term solution. The inherent insecurity 
of Beira's urban farming was not addressed in the resettlement plan, pointing to either a lack of understanding of Beira's contemporary land politics, or a lack of commitment to devising sustainable livelihood rehabilitation for farmers.

\subsubsection{The New Urban Spaces of the Urban Drainage Rehabilitation}

With the drainage rehabilitation project more than $9 \mathrm{~km}$ of degraded and overgrown drainage infrastructure was transformed into concrete channels, spanning several neighborhoods in Beira. The circa 25 hectare retention basin in the Maraza stands as a circular urban lake, which is rumored to become the focus of future real estate developments. Walking along these sleek concrete waterways, occasionally traversed by roads and walkways, it becomes apparent that this is one the largest public infrastructure investments which Beira has seen since independence.

As with the previous two cases however, the drainage itself was not the only new urban space created through this intervention. A purpose-built block of houses now stands in the neighborhood of Mutondo, home to a newly formed community of families who previously resided throughout the city. Encompassing several rows of fenced properties, a road, sidewalk, and recreational space it exudes a degree of uniformity typically found in 'Northern' suburbia, far removed from the urbanism that characterizes Beira. Compared to the houses of the other resettlement cases, excluding the third group of the SEZ resettlement, the houses and infrastructure were of far superior quality. In further contrast with the previous cases was the eagerness of the funding donor to be associated with the resettlement, with multiple billboards carrying the World Bank logo leaving no doubt as to the financer of this showcased resettlement.

Indeed the vast majority of household respondents were in agreement that the resettlement had constituted a significant improvement in terms of housing conditions. What was less apparent to those on the outside looking in however, was the fact that the households had received no assistance in terms of livelihood rehabilitation. This was determined not to be necessary in the resettlement plan, in apparent contradiction to national laws and World Bank standards. Thus, behind the walls of these model homes, widespread accounts emerged of increased vulnerability as families struggled to adapt to the new location. As stated tellingly by one respondent 'people are going to sleep hungry, they have a house, but they are going to sleep hungry'. Increased transport costs and utility bills meant that the drop in household income was further exacerbated by a rise in living expenses. It was only until a visit by World Bank staff after the resettlement that the need for ex-post livelihood assistance was identified. Six months after the resettlement however, during the final research fieldwork, such assistance had still not materialized.

As with the Chiveve case, this new community also found themselves within novel governance arrangements which bore no relation to 'alternative formality' or formal land governance regulations [32]. This was due to the fact that it was decided by project staff that the households would not be permitted to sell their houses, a measure based neither on national law or international standards. The reasoning behind this measure was that it would protect families from regressing in terms of living standards through the sale of their properties. As a consequence the resettled families were effectively frozen in the state of increased vulnerability which the resettlement had placed them in. However perhaps most problematic is the fact that households respondents did not appear aware of this measure until after the resettlement.

Although the displacement of the 490 farmers had not resulted in the direct creation of new spaces, their displacement invariably had social-spatial implications. Farming, like many livelihood activities in Beira, is strongly gendered and predominantly undertaken by women. Interviews with respondents which had lost their land revealed that many had taken up additional livelihood activities to compensate for the loss of farmland. Informal street vending known as negócios, which is a similarly gendered livelihood activity, emerged as a major replacement livelihood activity. Recent years have seen the municipality become increasingly hostile towards negócios activities, branding them as disorderly and dangerous. Thus we see that displacement of farmland feeds into other 
urban dynamics which will likely be the target of future eviction and displacement under the current municipal modernization strategy.

\section{Discussion}

As demonstrated in this article, previously neglected African cities are now becoming the recipient of international investment flows targeting the built environment [4,5]. A general trait of these divergent flows is that they are often premised on the availability of land, irrespective of the social utility of the infrastructures they seek to erect. As Africa's urban land is by definition already occupied, this surge in infrastructure interventions has come hand in hand with a surge in DID and resettlement. These dynamics have not been analyzed in detail in the urban context and exhibit some fundamental differences with DID and resettlement in the rural realm.

DID and resettlements related to investments in the rural context have often been found to be driven by the central state, together with international financial institutions and private investors $[6,7,35]$. In Beira however, we see that the notion of the 'state' is a problematic one, as it encompasses administrative levels governed by political competitors. As a result, the interest of the central state is arguably not to facilitate investments, but to frustrate them, creating an incentive at the municipality level to 'go it alone' where possible. These political-institutional fissures are by no means unique to Beira, and have been discussed elsewhere in debates on the politics of decentralized urban development [36].

The 'rogue' nature of these resettlement processes is further exacerbated by a lack of (inter)national civil society oversight, who generally do not have the resources or incentive to mobilize on behalf of relatively small DID populations. In cities with a negligible local civil society clout such as Beira, this effectively translates to a total lack of third party oversight during negotiations. This is likely to become a more common feature of urban DID and resettlements, as urban interventions generally occur on a much smaller scale then rural enclosures. Taken together with the contentious institutional politics, this creates a vacuum wherein multiple seemingly inconspicuous resettlements are negotiated, in a highly informal manner, bearing little resemblance to national policies, or the ideals of participative land governance which have informed large-scale rural resettlements (however superficially) $[4,6,7]$. This is by no means an issue of local institutional 'capacity' alone however, as each infrastructure project is shaped by a different cluster of (international) actors whose vested interests in resettlements differ greatly. The net outcome is multiple resettlements shaped entirely by the arbitrariness of project-specific interests.

However if we move away from viewing these resettlements as separate and unrelated, and see them as an expression of the same urban development regime, we can see that these individual DID populations are in fact part of an expanding urban DID population. We argue that such a perspective is more reflective of how urban DID populations see themselves, as close proximity of these interventions means that DID populations are often acutely aware of other resettlements nearby, serving as a basis of comparison to their own experiences. What becomes immediately clear from this perspective is the sheer divergence of the resettlement processes represented among this population. Moreover, these differences appear to be entirely random, bearing no discernable relationship to the losses or needs of affected populations. We argue, tentatively, that the multiplicity and close proximity of these interventions point to a distinctly 'urban' mode of resettlement politics, whereby the resettlement experiences of fellow urbanites provide a basis for articulating resistance and/or expectations with regards to new interventions. This points to potential cumulative impacts of (multiple) urban resettlements which extend far beyond the neat confines of 'project affected persons' alone.

These disruptive dynamics disappear entirely if we annex them from our evaluations of new infrastructures. In fact, by doing so, we could even argue that some of the cases discussed in this article constitute forms of sustainable infrastructure, due to their public utility and enhancement of climate resilience. Indeed this is a narrative which has seen much praise come to the leadership of Beira, 
whereby new infrastructures are celebrated as if appearing out of nowhere. While such a selective focus can perhaps be expected from political leaders, or indeed the many 'urban fantasies' planned in Africa, we argue that it is up to progressive deliberations of sustainable urban development to address the earlier 'moment' of displacement in a proactive manner [3]. This begins by extending the notion of sustainability to include the impacts of infrastructure development on established land claims. Such a broad conception of sustainability has long been the norm in rural development debates, which has resulted in numerous policy and scholarly efforts to reconcile land investments with land related impacts [4].

From a conceptual perspective we argue that DID and resettlement should not be understood as a destructive process alone, but a 'creative' one as well, whereby new social-spatial arrangements are forged. As demonstrated in this article, for each 'primary' infrastructure investment, we see additional 'secondary' spaces being created, taking the form of new structures and/or novel governance relations. This is particularly relevant to the urban context as these new spaces are integrated into broader urban dynamics and thus inevitably feed back into them. If we recognize these spaces as deliberate and fundamental components of 'development', as opposed to incidental and marginal, then they begin to resemble a distinct mode of urbanism which, as seen in Beira, bears little resemblance to established urban dynamics. As we have argued this is a mode of urbanism which, in its current guise, is fundamentally at odds with 'activation of citizens and rights' which sustainable infrastructure strives for [3] (p. 15). Consequentially there is an urgent need for this creative process to be brought to the fore, so that it can be debated on par with infrastructure development in a broader framework of urban sustainability.

\section{Conclusions}

With this article we have sought to provide a much needed empirical contribution to the emerging urban land debate. By looking behind the curtain of three high profile infrastructure interventions in Beira city, we have made visible the unregulated and contradictory processes of DID and resettlements upon which they have been premised. We have demonstrated that these land related impacts bear no discernable relationship to the social utility of the infrastructures in question, appearing a feature of both exclusionary neoliberal infrastructures (the SEZ) and arguable inclusionary sustainable infrastructures (public green spaces) in Beira. However, these findings should be understood as tentative and exploratory. Our intent is not to generalize, and substantial (comparative) empirical and conceptual work will be required to understand how these dynamics play out in other urban contexts. This implies a further exploration of the research agenda laid out by Zoomers et al. [4] which seeks to bridge the isolated 'containers' of debates on land governance research and debates on African urbanism/urban development. In reference to Pieterse et al. [3] we argue that this is not only a scholarly agenda, but one which requires a close and novel engagement with urban policy and politics.

Author Contributions: M.S.: Conceptualization, Methodology, Formal Analysis, Investigation, Writing-original Draft Preparation, Writing-Review \& Editing, and Funding Acquisition; K.O.: Conceptualization, Methodology, Writing-Review \& Editing, and Supervision; A.Z.: Conceptualization, Methodology, Writing-Review \& Editing, Supervision, and Project Administration; M.K.: Conceptualization, Methodology, Writing-Review \& Editing, and Supervision.

Funding: This research was funded primarily by LANDac, with complementary data collected within the context of research funded by the Netherlands Ministry of Foreign Affairs.

Acknowledgments: We would like to acknowledge Amilton Cesar and Pedro Zacharias for their tireless assistance and Sérgio Niquisse at the Catholic University of Beira for his support. We would also like to acknowledge Alda Salomão at Centro Terra Viva for her continued support and knowledge, as well as Alberto Magaia for providing an introduction to the city of Beira. Finally, we would like to thank the anonymous reviewers for their constructive input to the final version.

Conflicts of Interest: The authors declare no conflicts of interest. Complementary data collection was undertaken and financed through a project commissioned by the Netherlands Ministry of Foreign Affairs within the context of the Beira partnership, aimed at analyzing the politics of resettlement and displacement in Beira. Publishing rights to data acquired during this project was secured contractually by the author. The funders had no role in the 
design of the study; in the collection, analyses, or interpretation of data; in the writing of the manuscript, and in the decision to publish the results.

\section{References}

1. Simone, A. Infrastructure, real economies and social transformation: Assembling the components for regional urban development in Africa. In Africa's Urban Revolution; Parnell, S., Pieterse, E., Eds.; Zedbooks: London, UK, 2014; pp. 221-236.

2. Pieterse, E. Filling the void: an agenda for tackling African urbanization. In Africa's Urban Revolution; Parnell, S., Pieterse, E., Eds.; Zedbooks: London, UK, 2014; pp. 200-220.

3. Pieterse, P.; Parnell, S.; Croese, S. The 2030 Agenda: Sustainable Urbanisation, Research-Policy Interface and the G20. 2017. Available online: https:/ / www.africancentreforcities.net/wp-content/uploads/2017/05/ GIZ_nachhalt_Urbanisierung_160517.pdf (accessed on 16 May 2018).

4. Zoomers, A.; van Noorloos, F.; Otsuki, K.; Steel, G.; van Westen, G. The Rush for Land in an Urbanizing World: From Land Grabbing toward Developing Safe, Resilient, and Sustainable Cities and Landscapes. World Dev. 2016, 92, 242-252. [CrossRef]

5. Steel, G.; van Noorloos, F.; Klaufus, C. The urban land debate in the global South: New avenues for research. Geoforum 2017, 83, 133-141. [CrossRef]

6. Milgroom, J. Policy processes of a land grab: At the interface of politics 'in the air' and politics 'on the ground' in Massingir, Mozambique. J. Peasant Stud. 2015, 42, 1-22. [CrossRef]

7. Otsuki, K.; Achá, D.; Wijnhoud, J.D. After the consent: Re-imagining participatory land governance in Massingir, Mozambique. Geoforum 2017, 83, 153-163. [CrossRef]

8. Watson, V. African urban fantasies: Dreams or nightmares? Environ. Urban. 2014, 26, 215-231. [CrossRef]

9. Van Noorloos, F.; Kloosterboer, M. Africa's new cities: The contested future of urbanization. Urban Stud. 2017, 55, 1223-1241. [CrossRef]

10. Davidson, K.; Gleeson, B. The sustainability of an entrepreneurial city? Int. Plan. Stud. 2014, 19, $173-191$. [CrossRef]

11. Brenner, N.; Schmid, C. Towards a new epistemology of the urban? City 2015, 19, 151-182. [CrossRef]

12. Parnell, S.; Pieterse, E. Translational global praxis: Rethinking Methods and Modes of African Urban Research. Int. J. Urban Reg. Res. 2016, 40, 236-246. [CrossRef]

13. Parnell, S.; Pieterse, E. The 'Right to the City': Institutional Imperatives of a Developmental State. Int. J. Urban Reg. Res. 2010, 34, 146-162. [CrossRef]

14. Vanclay, F. Project induced displacement and resettlement: From impoverishment risks to an opportunity or development. Impact Assess. Proj. Apprais. 2017, 35, 3-21. [CrossRef]

15. Cernea, M.M. For a new economics of resettlement: A sociological critique of the compensation principle. Int. Soc. Sci. J. 2003, 55, 37-45. [CrossRef]

16. Vandergeest, P.; Idahosa, P.; Bose, P.S. (Eds.) Development's Displacements: Economies, Ecologies and Cultures at Risk; IBS Press: Vancouver, BC, Canada, 2007.

17. Bennett, O.; McDowell, C. Displaced: The Human Cost of Development and Resettlement; Palgrave Macmillan: New York, NY, USA, 2012.

18. Artur, L.; Hillhorts, D. Floods, resettlement and land access and use in the lower Zambezi, Mozambique. Land Use Policy 2014, 36, 361-368. [CrossRef]

19. Arnall, A. A climate of control: Flooding, displacement and planned resettlement in the Lower Zambezi River valley, Mozambique. Geogr. J. 2014, 180, 141-150. [CrossRef]

20. Rodrigues, C.U.; Frias, S. Between the City Lights and the Shade of Exclusion: Post-War Accelerated Urban Transformation of Luanda, Angola. Urban Forum 2016, 27, 129-147. [CrossRef]

21. Fält, L. From Shacks to Skyscrapers: Multiple Spatial Rationalities and Urban Transformation in Accra, Ghana. Urban Forum 2016, 27, 465-486. [CrossRef]

22. Mosselson, A. 'Joburg has its own momentum': Towards a vernacular theorisation of urban change. Urban Stud. 2017, 54, 1280-1296. [CrossRef]

23. Vines, A. Renamo's Rise and Decline: The Politics of Reintegration in Mozambique. Int. Peacekeep. 2013, 20, 375-393. [CrossRef] 
24. Igreja, V. Politics of Memory, Decentralisation and Recentralisation in Mozambique. J. S. Afr. Stud. 2013, 39, 313-335. [CrossRef]

25. Shankland, A.; Chambote, R. Prioritising PPCR Investments in Mozambique: The Politics of 'Country Ownership' and 'Stakeholder Participation'. IDS Bull. 2011, 42, 62-69. [CrossRef]

26. Hanlon, J. Following the donor-designed path to Mozambique's US $\$ 2.2$ billion secret debt deal. Third World Q. 2017, 38, 753-770. [CrossRef]

27. Kaarhus, R. Land, investments and publicprivate partnerships: What happened to the Beira Agricultural Growth Corridor in Mozambique? J. Mod. Afr. Stud. 2018, 56, 87-112. [CrossRef]

28. Sheldon, K. Machambas in the City Urban Women and Agricultural Work in Mozambique. Lusotopie 1999, 6, 121-140.

29. Sidaway, J.D.; Power, M. Sociospatial transformations in the 'postsocialist' periphery: The case of Maputo, Mozambique. Environ. Plan. A 1995, 27, 1463-1491. [CrossRef]

30. Sidaway, J.D. Urban and Regional Planning and Patterns of Uneven Development in Post-Independence Mozambique: An Overview; Collected Seminar Papers; Institute of Commonwealth Studies: London, UK, 1993; Volume 45, pp. 138-160.

31. Anderson, J.E.; Jenkins, P.; Nielsen, M. Who plans the African city? A case study of Maputo: Part 1-The structural context. Int. Dev. Plan. Rev. 2015, 37, 331-352. [CrossRef]

32. Anderson, J.E.; Jenkins, P.; Nielsen, M. Who plans the African city? A case study of Maputo: Part 2-Agency in action. Int. Dev. Plan. Rev. 2015, 37, 423-443. [CrossRef]

33. Earle, L. Stepping out of the twilight? Assessing the governance implications of land titling and regularization programmes. Int. J. Urban Reg. Res. 2014, 38, 628-645. [CrossRef]

34. Kihato, C.W.; Royston, L.; Raimundo, J.A.; Raimund, I.M. Multiple Land Regimes: Rethinking Land Governance in Maputo's Peri-urban Spaces. Urban Forum 2013, 24, 65-83. [CrossRef]

35. Fairbairn, M. Indirect Dispossession: Domestic Power Imbalances and Foreign Access to Land in Mozambique. Dev. Chang. 2013, 44, 335-356. [CrossRef]

36. Parnell, S. Defining a global urban agenda. World Dev. 2016, 78, 529-540. [CrossRef]

(C) 2018 by the authors. Licensee MDPI, Basel, Switzerland. This article is an open access article distributed under the terms and conditions of the Creative Commons Attribution (CC BY) license (http:/ / creativecommons.org/licenses/by/4.0/). 